\title{
Participation for What? A Policy-Motivated Approach to Political Activism
}

\section{Citation}

Platt, Matthew. 2008. Participation for what? A policy-motivated approach to political activism. Political Behavior 30(3): 391-413.

\section{Published Version}

http://dx.doi.org/10.1007/s11109-008-9054-0

\section{Permanent link}

http://nrs.harvard.edu/urn-3:HUL.InstRepos:3450076

\section{Terms of Use}

This article was downloaded from Harvard University's DASH repository, and is made available under the terms and conditions applicable to Other Posted Material, as set forth at http:// nrs.harvard.edu/urn-3:HUL.InstRepos:dash.current.terms-of-use\#LAA

\section{Share Your Story}

The Harvard community has made this article openly available.

Please share how this access benefits you. Submit a story.

\section{Accessibility}




\title{
Participation for What? A Policy-Motivated Approach to Political Activism *
}

\author{
Matthew B. Platt ${ }^{\dagger}$
}

December 28, 2007

\begin{abstract}
Normatively and intuitively, we conceive of political participation as an integral component of democratic policymaking. However, research on participation generally does not include policy considerations as part of individuals' decisions to engage in activism. I offer an Opportunity Model of participation that begins to study how policy goals shape individual participation and how aggregate participation shapes policymaking. The central argument is that individuals' policy goals allow them to recognize those moments when it is most efficient and/or effective to take action. Examining black participation from 1980 to 1994, I show that black Americans are more likely to participate when they face external threats, are embedded in social networks, and have greater access to policymakers. Most importantly, the recognition of these opportunities varies according to individuals' resources. This research moves beyond the discussion of who participates to address the equally fundamental question: participation for what?
\end{abstract}

${ }^{*}$ I would like to thank Fredrick Harris, Valeria Sinclair-Chapman, Richard Niemi, Kevin Clarke, Gerald Gamm, James Endersby, Paul Martin, Arthur Spirling, David Carter, and Eduardo Leoni for helpful comments on earlier drafts of this paper; Janet Box-Steffensmeier for data; and the star lab for use of its resources in the writing and analysis of this paper. The normal caveat applies.

${ }^{\dagger}$ Department of Political Science; University of Rochester; plat@mail.rochester.edu 
The aim of participation research is (or at least should be) to connect individuals' participation decisions to policy outcomes. Normatively, we view the political activity of citizens as an essential element of a democratic policy process (Verba, Schlozman and Brady 1995, 1-2). Intuitively, we think that individuals engage in political actions because they want to influence policymaking. Yet, the dominant theories of political participation do not include policy considerations as part of individuals' decisions to take action (Verba and Nie 1972; Verba, Schlozman and Brady 1995). As a result, our extensive knowledge about who participates is divorced from the equally fundamental question of why people participate: participation for what? I address this fundamental question by devising an opportunity model of policy-motivated participation, and then I apply that model to black politics. The research is guided by two questions: how do social, economic, and political environments shape black participation decisions, and what are the consequences of black participation for congressional responsiveness to black issues?

Addressing these questions contributes to a growing literature that integrates political participation into larger discussions of how individual behavior is shaped by exogenous events. The foundational work in participation explains how individual characteristics are critical for understanding political activity in some generic democracy (Brady, Verba and Schlozman 1995). Conversely, social movements research emphasizes how specific macro-contextual features influence aggregate mobilization (Schussman and Soule (2005) is a notable exception). This paper joins more recent scholarship that transforms the standard model of generic democracy into a contextualized political world involving disparities in local services (Marschall 2001, 2004), anti-terrorism policies (Cho, Gimpel and $\mathrm{Wu} 2006$ ), and descriptive representation (Griffin and Keane 2006). These studies make the point that political participation is not the result of personal characteristics or macro-context; it is the result of the interactions between these factors.

I extend this research by asserting that participation decisions are shaped by political opportunities - recognized links between changes in broad contextual environments and an individual's policy concerns (McAdam 1999; McAdam, Tarrow and Tilly 2001; Meyer 2004). Rational activists should participate when economic, social, and political conditions are more favorable to the realization of their policy goals. Black Americans' shared racial identity and sense of "linked fate" create 
a common core of black issue concerns (Walton 1985; Dawson 1994; Walton and Smith 2003), so the participation decisions of black individuals should change according to opportunities for responsiveness to black policy demands. Examining individual-level data on black participation from 1980 to 1994, I show that black Americans are more politically active when they face some external threat, have greater access to policymakers, and there are stronger social networks. In addition, these effects are contingent upon individuals' education and income. However, in the aggregate, this policy-motivated black participation has no significant impact on congressional attention to black issues.

The remainder of the paper proceeds in five sections. Section 1 presents the Opportunity Model of participation and applies it to black politics. Section 2 details how black participation, political opportunities, and congressional responsiveness to black issues are measured. In addition, this section discusses the two separate data analyses for investigating the impact of opportunities on black participation and the policy consequences of that participation. Section 3 presents the core findings from this analysis, and Section 4 concludes with some of the contributions this research makes to our understandings of political participation and black politics. The message is straightforward: political opportunities shape policy-motivated activism, but that activism does not necessarily yield policy results.

\section{An Opportunity Model of Participation}

The Opportunity Model of participation is based on the simple assumption that individuals engage in political action because they want to influence policy. ${ }^{1}$ Given this assumption, we should expect individuals to strategically participate when it is relatively more effective and/or efficient to do so; when the ratio of benefits to costs is higher. Opportunities are those contextual features that set the cost/benefit constraints within which participation decisions are made. More broadly, "constraints"

\footnotetext{
${ }^{1}$ Although collective action problems (Olson 1971) and the calculus of participation (Riker and Ordeshook 1968) have rendered this assumption highly dubious, the literature has pushed against these concerns over the past fifteen years. Game theoretic formulations of participation have shown how information cascades can overcome collective action problems (Lohmann 1993, 1994), and Schlozman, Verba and Brady (1995) demonstrate empirically that individual participation is motivated by collective interests. However, research has also shown that many people participate for social rather than policy benefits.
} 
can also be thought of as the individual-level attributes highlighted by the Civic Voluntarism Model - resources, political engagement, and recruitment (Verba, Schlozman and Brady 1995). An open opportunity is characterized by fewer constraints on activity - higher ratios of benefits to costs, more resources, greater political engagement, and/or higher levels of recruitment activity. Conversely, a closed opportunity more strictly constrains individuals' participation decisions. People should be more likely to take action when there are open opportunities, and they should be less likely to take action when there are closed opportunities.

However, as any high school guidance counselor knows, opportunities are worthless if nobody takes advantage of them. In social movements research, political opportunities are conceptualized as being specific to certain tactics and certain movements (Meyer 2004). As such, McAdam, Tarrow and Tilly (2001) argue that opportunities must be recognized before mobilization can occur, and this recognition varies according to how individuals identify themselves. I use the recognition of opportunities to incorporate policy considerations into participation decisions. Namely, individuals' policy concerns form the basis of the identity that is used to recognize open and closed opportunities. I argue that individuals who identify with similar policy demands comprise informal (and sometimes formal) constituencies of interests, and the size of these constituencies fluctuates according to the opportunities arising from larger social, political, and economic environments. Black Americans' shared racial identity and historical experience with racial injustice has fostered a sense of "linked fate," and as a result, black Americans generally adhere to a common core of policy interests that can be classified as "black issues" (Walton 1985; Dawson 1994; Tate 1994; Walton and Smith 2003). The Opportunity Model of participation states that this common policy identity should allow individual black civic activism to be shaped by the opening and closing of opportunities. In this paper, I focus on three types of opportunity: external threats, access, and social networks.

\section{$1.1 \quad$ External Threats}

An external threat allows individuals to tap into their group identity and rally for renewed, more innovative efforts (Dyke and Soule 2002; Dyke 2003; McAdam, Tarrow and Tilly 2001). As a result of tapping into this group identity, political interest increases, and people are more likely 
to participate. In the participation literature, this idea is best expressed through the role blame attribution plays in studies of economic voting (Kinder and Kiewiet 1979; Feldman 1982; Arceneaux 2003). Welch and Foster (1992) show that this role is further enhanced by black Americans' group consciousness, which places the blame on institutional rather than individual failings. Tate (1994, 118-121) argues that Ronald Reagan's administration served as such an external threat, leading to a record high black turnout in the 1984 election. Looking at cumulative data from the National Election Studies, there is some empirical evidence that black Americans were particularly dissatisfied with the Reagan administration. Of the four Republican presidents between 1968 and 2000 (Nixon, Ford, Reagan, and H.W. Bush), only Nixon has a lower mean rating on the feeling thermometer. However, Reagan's mean thermometer ratings sport an 18 point difference between white and black respondents while ratings for the other three candidates only show an 11 point difference by race. The implication is that Reagan was disproportionately viewed negatively by black people.

This apprehension was not without cause. Reagan's poor record on civil rights - particularly his vetoes of the Martin Luther King Holiday and sanctions against apartheid - have been well documented by previous research (Walton 1988; Smith 1996). In addition, the unemployment rate for black Americans was, on average, twice the rate for the nation as a whole (15.5\% compared to $7.5 \%$ ). The poverty rate for black people grew during Reagan's first three years in office (from 32.5 in 1980 to 35.7 in 1983), and crack cocaine emerged during the 1980s, devastating the lives of many poor black people in America's cities. ${ }^{2}$ Although Reagan is certainly not responsible for all of these negative trends affecting black Americans in the 1980s, his administration bore much of the blame nonetheless.

Hypothesis 1: The Reagan administration was an external threat to black Americans, so black people will be more likely to participate when Reagan is in office.

\footnotetext{
${ }^{2}$ Data provided by the U.S. Bureau of the Census Current Population Survey, Annual Social and Economic Supplements. The U.S. Drug Enforcement Administration lists the beginning of the crack epidemic as 1984, but the first instances of "crack houses" occurred in Miami in 1982.
} 


\subsection{Access Opportunities}

Access refers to those moments when either the government is particularly responsive to a given group or when there are movement allies in positions of power. Generally, access opportunities raise the ratio of benefits to costs because less activity is required to achieve policy outcomes (Cress and Snow 2000; Amenta, Olasky and Caren 2005). In terms of having allies in positions of power, the literature on minority participation conceives of access opportunities as political empowerment. Bobo and Gilliam (1990) argue that black mayors empowered their black constituents by increasing their levels of political trust, knowledge, and efficacy. As a result, black Americans participated at higher rates when they lived in a city with a black mayor. Later work has expanded these findings to show the participatory benefits of descriptive representation for black people, latinos, and women at all levels of government (Gay 2001, 2002; Lawless 2004; Barreto, Segura and Woods 2004; Griffin and Keane 2006). However, the race and representation literature emphasizes the importance of substantive representation (Swain 1995; Cameron, Epstein and O'Halloran 1996; Lublin 1997), so black Americans may also find allies in the form of liberal Democrats who are receptive to black policy demands.

Hypothesis 2: Having allies in Congress is an access opportunity for black Americans, so black people will be more likely to participate as the number of congressional allies increases.

As stated above, access refers to more than just having allies in positions of power. An access opportunity also refers to when the government or broader public is more receptive to addressing certain issues. McCammon et al. (2001) show that the Women's Suffrage Movement benefitted from exogenous changes in the nation's perception of women's roles. Similarly, Lee (2002) posits that the success of the Civil Rights Movement was due to the endogenous process of altering public opinion on black issues. Given that black issues are usually liberal policies that envision a larger role for the federal government (Hamilton and Hamilton 1997; Walton and Smith 2003), rising conservatism could pose a closed opportunity to black Americans.

Hypothesis 3: A receptive public mood is an access opportunity for black Americans, so they will 
be less likely to participate as the nation becomes more conservative.

\subsection{The Importance of Networks}

Social networks make mobilization more efficient, diffuse tactics across organizations, and foster the group identities that are activated by external threats (Morris 1984; McAdam and Paulsen 1993; Soule 1997; McAdam 1999). The participation literature asserts that social and information networks raise individuals' levels of political interest and knowledge, increasing their likelihood of engaging in activism (Johnson, Stein and Wrinkle 2003; McClurg 2003; Bowers 2004; Cho, Gimpel and Dyck 2006). Furthermore, Cho (2003) shows that campaign contributions by Asians follows a pattern of diffusion, and Kenny (1992) finds that people participate more when they are part of an active social network. The relationship between networks and participation is amplified in black politics. Interaction among black people socializes them to link their own fate with that of the larger black community. Given the prevalence of racial frames in these interactions, black people are then able to take the cognitive shortcut of basing political decisions on group concerns rather than individual concerns (Walton 1985; Dawson 1994; Harris, Sinclair-Chapman and McKenzie 2006). As a result, black peoples' political orientations - various combinations of trust and efficacy - are more conducive to participation (Verba and Nie 1972; Shingles 1981; Guterbock and London 1983; Gurin, Hatchett and Jackson 1989; Mangum 2003; Southwell and Pirch 2003). ${ }^{3}$

Hypothesis 4: Black Americans who are part of social networks are more likely to participate than those who are not embedded in networks.

The Opportunity Model of participation predicts that the common policy interests of black Americans will lead them to recognize changes in threat, access, and network opportunities. However, nothing has been said about the consequences of that participation for congressional responsiveness to black issues. Previous work has demonstrated theoretically that political participation serves as a signalling device to policymakers (Austen-Smith and Wright 1994; Kollman 1998). The basic idea is that legislators want to govern in the majority's interest, but they are uninformed about what that interest actually is. High levels of activism in favor or in opposition to a policy

\footnotetext{
${ }^{3}$ There is some debate as to which combination of trust and efficacy has the greater impact on black participation.
} 
serves to inform policymakers about the preferences of the general public, and then they enact policies accordingly (Lohmann 1993). Mobilization in these models usually follows the leader-driven approach adopted by Rosenstone and Hansen (1993). The Opportunity Model of participation is more in line with the work of Lohmann (1994), who shows how large-scale activism occurs in the absence of a mobilizing leader or organization. When black Americans' common policy interests lead them to recognize the opening of access opportunities, then they should participate at higher rates. These heightened levels of black participation signal the salience and credibility of black issues to Congress, which responds with greater attention to black issues.

Hypothesis 5: Rising levels of aggregate black participation should lead to greater congressional attention to black issues.

\section{Data and Methods}

In order to evaluate these five hypotheses we need measures of participation, external threats, access, social networks, and congressional responsiveness. The first - and most important - task is to find suitable measures of participation. Studies of participation are generally interested in who participates more, so they measure political activity through some type of index. Conversely, the Opportunity Model posits that certain individuals should engage in certain types of activity at certain times, so rather than creating an index of participation, I am interested in the binary choice to engage in a form of activism. ${ }^{4}$ In order to capture variation in the opportunities that structure these binary choices, I also need data on individuals' participation decisions over some period of time. Both of these concerns are addressed by the Roper Social and Political Trends data, which includes almost monthly survey questions about the political activities of respondents from 1980 to 1994 (Brady, Putnam et al. 2001).

The Roper Center asks about twelve activities. ${ }^{5}$ Of these twelve forms of participation, five

\footnotetext{
${ }^{4}$ The idea is to examine how the effects of opportunities vary across different forms of activity. That variation would be lost in a participation scale.

${ }^{5}$ The Roper Survey asks respondents "Now here is a list of things some people do about government or politics. Have you happened to have done any of those things in the past year?" The twelve activities are: contacting a member of Congress, attending a public meeting on local affairs, attending a political rally, seeking/holding political office, writing a letter to a newspaper, signing a petition, working for a political party, making a speech, serving
} 
relate to individual efforts to communicate one's preferences - contacting a member of Congress, attending a public meeting, writing a letter to a periodical, writing an article for a periodical, and making a speech. Three activities are concerned with organizational affiliation and service - serving on a committee in a local organization, serving as an officer for a club or organization, and being a member of a "good government" organization. Lastly, there are three forms of participation that incorporate individual efforts into some broader collective action - attending a political rally, working for a political party, and signing a petition. Given the impracticality of analyzing how all of these activities are shaped by opportunities and in turn influence congressional attention, I focus on these last three acts that involve collective efforts to influence policy.

The Opportunity Model emphasizes how individuals independently combine their activity into constituencies of interests. Signing petitions, working for parties, and attending rallies are all individual choices to engage in a collective enterprize of influencing policy. Arguably, contacting a member of Congress could be part of a larger letter-writing campaign. However, much of citizens' interactions with members of Congress deal with requests for more individualized casework (Fenno 1978). Writing articles, letters, or speeches do not necessarily involve any attempt to sway policymakers. Indeed, these efforts are generally aimed at expanding knowledge or public support around an issue. Petitions, rallies, and party work are explicitly geared toward influencing the who and how of policymaking. ${ }^{6}$ Thus, there are three dependent variables for black individuals' participation decisions: separate binary indicators for whether a respondent signed a petition, attended a political rally, and worked for a political party. In order to examine black participation more generally, I include a binary measure of whether a respondent engaged in at least one of the nine non-organizational forms of participation as a fourth dependent variable.

I hypothesize that these four measures of black participation are shaped by external threats, access opportunities, and social networks. The Reagan administration has already been highlighted

on a committee in a local organization, serving as an officer for a club or organization, being a member of a "good government" organization, or writing an article for a periodical.

${ }^{6}$ This explanation would suggest that voting or protest should also be included as dependent variables. Unlike the three activities I focus upon, individuals do not have control over when they have the option to vote. I am interested in individual choices when there is relatively little governmental structure dictating their choices. Protest fits within the type of activity that is the subject of this research. From a practical point of view, there is no data on individual decisions to protest that covers a meaningful span of time. For these reasons, I analyze non-voting, non-protest participation. 
as a threat to black Americans during the period of this study, 1980-1994. As an independent variable, I measure the Reagan threat (labeled "Reagan Threat") as a dichotomous variable taking a value of one when Ronald Reagan is in office. However, there should be some way to distinguish between the general difficulties black people faced during the Reagan administration and the economic difficulties that disproportionately harmed black Americans during Reagan's first term. The black unemployment rate, which is usually double the rate of unemployment generally, is a good indicator of the disparate effects that economic downturns can have on black people, so I include it as a second measure of external threats. This independent variable (labeled "Black Unemployment") is the quarterly seasonally adjusted rate for black Americans reported by the Bureau of Labor Statistics. When there are more external threats - black unemployment rises and/or Reagan is in office - black people should be more likely to participate.

In the above discussion, access opportunities were conceived in two ways: having allies in positions of power and favorable public sentiment. There are two measures of allies. To capture the idea that descriptive black representatives provide enhanced legislative service to black Americans, I include the number of black members of Congress who hold committee or subcommittee chairmanships as an independent variable (labeled "Black Chairs"). However, the race and representation literature also highlights the role of substantive representation, which does not necessarily require black members of Congress. This concept is operationalized as the quarterly number of black issue bills introduced in Congress (labeled "Black Bills"). ${ }^{7}$ The second hypothesis for access opportunities (Hypothesis 4) involved conservatism. I use the quarterly percentage of Americans who self-identify as conservative according to monthly polls by CBS News/New York Times as an independent variable that measures conservatism (labeled "Percent Conservative"). When there are open access opportunities - increased allies, more black bills, and lower percentages of conservatives - black people should be more likely to participate.

While the other opportunities have been measured at the aggregate level, social networks are operationalized as an individual-level variable. I measure social networks as a dichotomous variable (labeled "Organizational Activity") taking a value of one for respondents who engage in at least

\footnotetext{
${ }^{7}$ This measure was constructed by searching the Library of Congress's Thomas server under the subject term "blacks."
} 
one of the following activities: served on a committee for a local organization, served as an officer in an organization or club, or was a member of a good government organization. Basically, rather than trying to gauge the strength of black social networks in some aggregate sense (such as church attendance or NAACP membership), I am interested in whether an individual is engaged in social networking. Black people who are part of social networks will be more likely to participate. Finally, since the Opportunity Model asserts that opportunities interact with the constraints of participation, I include standard individual-level characteristics - age, household income, and education level.

From this discussion of the data, we see that there are four binary dependent variables that are functions of both aggregate- and individual-level explanatory variables. I employ a two-stage random effects logit developed by Borjas and Sueyoshi (1994). First, separate logit models are estimated for each quarter from 1980 to 1994. These models regress participation on age, household income, education, and organizational activity, yielding 58 estimated coefficients for these four variables and the intercept. Second, OLS is used to regress these 58 coefficients on the aggregatelevel variables (Reagan threat, black unemployment rate, number of allies, number of black bills, and percent conservatives $)^{8}$, and that is done for all five of the variables from the first stage (the intercept, age, education, household income, and organizational activity). The basic idea is to estimate the macro- and micro-level effects in separate steps. That is, the first step of the estimation provides the average effects for each time unit, and the second step treats these average effects as linear functions of unit-varying factors. ${ }^{9}$ This creates a fully interactive model capable of teasing out variations in responses to opportunities.

Estimating the effects of opportunities on black participation is only half of the analytical task. The other half is to estimate the impact of aggregate black participation on congressional attention to black issues. As an independent variable, aggregate black participation is measured as the quarterly proportion of respondents who sign petitions, attend rallies, or work for parties. Due

\footnotetext{
${ }^{8}$ The Roper Survey asks respondents "Now here is a list of things some people do about government or politics. Have you happened to have done any of those things in the past year?" As a result of this wording, the aggregate variables are lagged by four quarters.

${ }^{9}$ As with any multi-stage analysis, I make the requisite corrections to the covariance matrices highlighted by Huber, Kernell and Leoni (2005).
} 
to the high collinearity between these measures of participation, I run four separate models - one for each measure of aggregate participation. In addition to aggregate black participation, I specify congressional attention as a function of access opportunities, so the number of black committee and subcommittee chairs, the number of black issue bills, and the percent of conservative identifiers are included as explanatory variables. Following the standard convention in the agenda setting literature (Baumgartner and Jones 1993; Jones and Baumgartner 2005; Sheingate 2006), I measure congressional attention as the quarterly count of hearings held on black issues. ${ }^{10}$ Given that the dependent variable is a count, the relationship between congressional hearings and aggregate black participation is analyzed using a poisson count model. ${ }^{11} \mathrm{I}$ have argued that policy-motivated black participation is governed by the political opportunity structure. Now that claim can be assessed.

\section{Results}

As stated above, the first portion of the data analysis is to understand how opportunities shape black participation. Since I have estimated a fully interactive logit model of individual participation, the interpretation of coefficients is not entirely straightforward. In order to ease the presentation of results, tables of coefficients are relegated to the appendix. Instead Table 1 presents first differences in the predicted probabilities of black participation. ${ }^{12}$ For example, the entry in the seventh row and first column shows that a one-unit increase in education raises the probability of engaging in at least one of the nine acts on the Roper Survey by 0.174 . The parentheses show the $95 \%$ confidence boundaries, so in this case the change in probability is statistically significant. ${ }^{13}$ In general, education and income behave as expected from the standard findings in the participation literature. More educated black people are more likely to sign petitions, work for a political party, or attend a political rally. By the same token, those with higher incomes participate more overall and are

\footnotetext{
${ }^{10}$ This measure was constructed using a Lexis-Nexis Congressional Universe search for the keyword "blacks."

${ }^{11}$ Diagnostics showed that the hearings were independent, and there were no signs of over-dispersion when the models were ran using a negative binomial.

${ }^{12}$ First differences for education, age, and organization represent a one-unit change. The remaining variables represent changes of one standard deviation from the mean.

${ }^{13}$ First differences and confidence intervals were calculated using the CLARIFY procedure (though not the actual program) outlined by King, Tomz and Wittenberg (2000). The baseline profile that these changes are compared to is a black person between the ages of 35-39 with a high school education who earns \$12,242.41 (in 1982 dollars) and is not affiliated with an organization.
} 
more likely to sign petitions. However, there is some divergence from the usual findings for age and income. There is no relationship between an individual's age and the probability of participation, and income does not appear to influence decisions to work for a political party or attend a political rally. These findings highlight the value of looking at the types of participation separately. Age is an important factor for voting, but has no effect on non-voting black participation. Similarly, both party work and rally attendance require a willingness to volunteer one's time that, apparently, does not correspond to having a higher income. Still, this paper is primarily interested in the role opportunities play in black participation decisions.

[Table 1 about here.]

There are three types of opportunities: external threats, access, and social networks. I argued that rising unemployment and the turbulence of the Reagan years (at least from the perspective of black Americans) constituted external threats that use a common racial identity to galvanize black people. That certainly appears to be the case for the Reagan Threat. During his administration, black people were more likely to participate in all three forms of activity. Unemployment presents a different story; it seems to have no effect on rates of black participation. Rather than responding to tangible Reaganomic difficulties (such as high unemployment), it is the more general problems, such as civil rights enforcement and the crack epidemic, that result in higher probabilities of black participation.

Access opportunities were measured as general conservatism, congressional allies, and the introduction of black issue bills in Congress. Interestingly, access opportunities only influence decisions to work for political parties. As expected, there is a slight decline in the probability of working for a political party when a larger percentage of the nation identifies as conservative, and the probability of party work increases when more black issue bills are introduced in Congress. However, increasing the number of black people who hold committee or subcommittee chairs leads to a small decrease in participation. Though unexpected, this finding reflects theoretical developments within the social movements literature. After a certain point, entrenched allies provide sufficient access to preclude political activity (Soule and Zylan 1997; Jenkins, Jacobs and Agnone 2003; Amenta, Olasky and Caren 2005). Conversely, the type of legislative support supplied through favorable 
bill introductions is held as providing increased access without lessening the need for participation altogether (McAdam 1999; Cress and Snow 2000). In either case, the relatively small substantive effects suggest that access opportunities do not have broad influence over black Americans' decisions to engage in activism.

Contrary to access opportunities, social networks are a comprehensive boon to black participation. Basically, black individuals who are embedded in social networks are substantially more active than those who operate outside of these networks. On average, being affiliated with an organization raises the probability of participating in at least one act by 0.826 (meaning that it is a virtual certainty), and being involved in organized networks raises the probability of signing petitions, working for political parties, and attending rallies by $0.341,0.027$, and 0.157 respectively. These findings are in accord with the argument in Leighley (1996) that organizations contribute to an unintentional mobilization of political activity.

Table 1 also provides insight into differences across the types of participation. The importance of external threats to individuals' decisions to attend rallies may reflect the importance of political rallies as articulations of grievances. However, working for political parties could be more instrumental in shaping policy, so opportunities that determine access to policymakers play a greater role in decisions to engage in party work. Conceiving of political acts as serving distinct policy purposes may also explain the null findings for overall participation. As a mix of different types of participation that serve different roles, specific opportunities should not have any systematic effect, which is what Table 1 reveals for access opportunities and the threat of unemployment. Finally, social interaction is so essential to black participation, and the Reagan threat was so pervasive that individuals were driven to higher levels of activity - regardless of the type of political act. Although these explanations are merely conjectures, they reflect the sorts of insights that are possible through a policy-motivated approach to participation research.

\subsection{Opportunities for Interaction}

The Opportunity Model emphasizes that the recognition of opportunities depends upon individual identity. In this sense, it is not enough to know what the general effects of opportunities are. We 
also need insight into how the effects of changes in social, political, and economic environments vary according to individuals' characteristics. Tables 2-4 present the interaction between opportunities and three individual-level characteristics: organizational affiliation, education, and income.

[Table 2 about here.]

As with Table 1, the cell entries for these three tables are the change in probability compared against the previously stated baseline. The top row shows the effect on participation when only the individual-level variable changes, and the subsequent rows are the effect when both the individuallevel characteristic and the opportunity variable change. Entries in bold mean that the impact of the individual-level variable is enhanced by the interaction with an opportunity variable. For example, Table 2 demonstrates that rising black unemployment lessens the impact of social networks on overall participation, but it enhances the value of social networks for higher rates of petition signing.

Table 2 adds a layer of complexity to our previous findings about opportunities. With the exception of overall participation, black people who are embedded in organizational networks recognize rising unemployment as an external threat, so the probabilities for signing petitions, working for political parties, and attending rallies all increase in response to black unemployment rates. In a counter-intuitive finding, black people with some organizational affiliation are actually less likely to participate in response to the Reagan administration than people who are not connected to social networks. Lastly, the access variables follow a surprising pattern, given the results from Table 1. Having more black committee chairs in Congress increases overall participation, petition signing, and rally attendance. It seems that members of social networks have a better grasp of the strategic logic. Black committee chairs imply a greater chance for rapid change, so organizationally affiliated individuals respond with higher levels of activity to take advantage of the opportunity. A more striking pattern is observed for growing conservatism. Rather than recognizing conservatism as an issue of access, those in social networks respond to growing conservatism as an external threat, thus increasing the probability of participation.

Table 3 presents the interaction of education and opportunities. While there are a number of interesting results here, I will restrict attention to unemployment, the Reagan threat, conservatism, 
and rally attendance. Black Americans who lack high levels of education have an intense reaction to the Reagan administration as threatening their interests. However, the highly educated do not respond to the general specter of Reagan himself; they respond to the negative policy consequences associated with his administration - higher rates of black unemployment - and the increasing conservatism that administration represents. If we assume that higher levels of education are a good proxy for political knowledge, then Table 3 may present an interesting story about how political knowledge or sophistication affect the recognition of external threats. As stated above, politically sophisticated black people view conservatism not as closed access but as a mobilizing threat. The other interesting point is the difference in the results for rally attendance in Tables 2 and 3. Being part of social networks translated almost all opportunities into increased probabilities of attending political rallies. However, with the exception of unemployment, higher levels of education translated all opportunities into lower probabilities of attending political rallies. Organizations respond to contextual developments with collective rallies. Those with higher levels of education invest their participatory resources elsewhere.

[Table 3 about here.]

As stated above, age does not have a significant effect on any of the four measures of participation, and income is only relevant to the decisions for overall participation and petition signing. Thus, Table 4 presents the interaction of income with opportunities for overall participation and signing petitions. Unlike the nuanced, conditional relationships unveiled in Tables 2-3, higher income produces an almost across the board spike in the probabilities of participating generally or signing a petition. Interestingly, the presence of black committee and subcommittee chairs is an exception to these positive effects. Griffin and Keane (2006) find that the participatory benefits of descriptive representation are conditioned on ideology. Perhaps black Americans with aboveaverage incomes are sufficiently more conservative that they do not necessarily view black members of Congress as their allies. However, as Dawson (1994) shows, those with higher incomes have not lost touch with a sense of racial identity. Indeed, Gay (2004) shows that middle-class black people are more militant on racial matters. As a result, higher income levels enhance the recognition of external threats and black issue legislation, but the liberalism of black elected officials diverges too 
much from the ideal points of more well-off black Americans.

[Table 4 about here.]

Adopting the Opportunity Model approach to participation provides new angles of inquiry in terms of the differences between acts and individual-level resources. These differences are obscured when we do not focus on a broader politicized context.

\subsection{From Policy Motivation to Policy Outcomes}

Black Americans are more likely to engage in participation when they are attached to social networks, when they recognize racial threats and allies, and when there is a less-conservative political climate. I have argued that participation serves as a signal to policymakers of credibility and salience, so when more black people are active, congress should be more responsive to black issues. Conversely, sparse participation should then send a signal that policy ideas are lacking in either credibility or salience, and therefore are not worth the legislator's resources (Lohmann 1993; Austen-Smith and Wright 1994).

[Figure 1 about here.]

Figure 1 lends some insight into the nature of the signal being sent by black participation. Figure 1(a) shows the predicted probability that a respondent will engage in at least one act of participation. Figure 1(b) is a similar plot of the probability that a respondent will have worked for a political party. The relatively low levels of black participation displayed in these plots sow the seed of doubt regarding the ability of black activism to force increased levels of policy responsiveness from the government. Our final task is to investigate whether policy-motivated black participation leads to increased congressional attention to black issues.

[Table 5 about here.]

The results presented in Table 5 suggest that there is no relationship between black participation and congressional attention to black issues. Due to the collinearity among the types of participation, four separate models were ran for each form of political activity. Table 5 presents the coefficients 
and standard errors from the poisson estimation. Regardless of the form of political participation, there is no relationship between aggregate activity and congressional responsiveness. This null relationship could be indicative of the aforementioned failure to convince legislator's of the worth of black issues. However, the literature on white racial attitudes offers an alternative explanation. Studies of white racial attitudes argue that white Americans oppose racialized issues because these group-specific issues are contrary to American ideals of individualism and hardwork (Sears, hensler and Speer 1979; Sniderman et al. 1991; Tarman and Sears 2005). Furthermore, white opposition to black issues is reinforced by beliefs in negative stereotypes about black people (Peffley, Hurwitz and Sniderman 1997; Virtanen and Huddy 1998). As a result of these two trends, black issues will face entrenched white opposition unless they are framed in more universal terms (Sniderman et al. 1996; Krysan 2000). I have argued that a racialized view of political, economic, and social events are what allow black Americans to recognize political opportunities. Black participation motivated by such racialized policy issues may trigger white opposition. The plausible result is a null relationship between black activism and congressional responsiveness because black participation has been drowned out by higher levels of white participation.

One way of making some sense of whether the white opposition argument is plausible is to compare the participation rates for black and white people over time. If white people participate at lower levels than their black counterparts, then a white opposition argument would not seem to make much sense. Figure 2 shows the monthly rates of participation for white and black respondents and the difference between these rates from 1973 to 1994. The message from both Figures 2(a) and $2(\mathrm{~b})$ is that the white opposition argument cannot be ruled out by the data. White Americans consistently participate at higher levels than black Americans. Interestingly, there is a marked decline in the participation gap during the 1980s. Perhaps this is another indication of the broader effects I have associated with the Reagan administration. Nonetheless, it is quite possible that black participation was simply overshadowed by white participation during this period, so we find no relationship between black activism and congressional attention to black issues. Although black participation is policy-motivated, in the aggregate, it does not appear to produce policy outcomes.

[Figure 2 about here.] 


\section{Conclusion}

In this paper, I have attempted a full exploration of policy-motivated black participation. Using a simple assumption that people participate to influence policy, we found that political opportunities play an important role in individuals' decisions to participate. Indeed, the impact of external threats and access vary across the types of participatory activity as well as across levels of education, income, and social network affiliation. Black individuals are more likely to participate when there is higher unemployment, during the Reagan administration, when they are part of social networks, and when there is greater access to policymakers. Despite the impact of these policy-related factors on black participation, aggregate black political activity was found to have no relationship with congressional attention to black issues.

There are two important contributions this research makes to the study of political participation. First, it offers the Opportunity Model as a framework for future analyses of participation. This policy-motivated approach differs from the standard practice in participation research because it examines individual types of activity, the primary explanatory variables are contextual rather than at the individual level, and it tries to explore interactions between macro-context and individual characteristics. Of course, this approach also brings a new set of data problems. We must have data that allows for either temporal or spatial changes in opportunities, and there must be some measure of policy-motivations. I have used race as a proxy for policy interests in this paper, but the ideal would be to have a more exact measure of the intended consequences of political actions. Second, I attempt to connect non-voting political participation to actual policy outcomes. This is an important step for both the participation and agenda setting literatures. Understanding how participation affects policy would provide new insights into how participation decisions are actually made. Similarly, scholars of agenda setting argue that the entrance of new participants into the policy arena is crucial for placing new items on the agenda (Cobb and Elder 1972; Schattschneider 1975; Cobb, Ross and Ross 1976; Baumgartner and Jones 1993); however, there are not any studies in this literature that empirically establish such a connection. Although I report only null findings in this paper, it is still an important first step toward linking political activity and policymaking.

Finally, this paper raises interesting questions for students of black politics. There seems to 
be fundamental tension between theories of black participation and strategies of successful black agenda setting. Black participation research trumpets the importance of black consciousness to mobilizing higher levels of black activism (Walton 1985; Gurin, Hatchett and Jackson 1989; Tate 1994; Dawson 1994); yet studies of black agenda setting stress the necessity of gaining broader nonblack support for black issues to become public policy (McClain 1993; Lee 2002). In this paper, that tension results in an insignificant relationship between participation and policymaking. Future research needs to think more carefully about how strategies of black agenda setting correspond to strategies of political mobilization. Alternatively, these findings could reflect the long-standing argument that institutionalized politics is simply not effective at securing policy responsiveness for black issues. Instead, greater attention should be given to the potential influence of protest activity (Smith 1992). The basic point is that whenever we study individuals' decisions to participate in politics, we must begin with a basic question: participation for what? 


\section{Appendices}

A Tables of Coefficients for Each Type of Participation

[Table 6 about here.]

[Table 7 about here.]

[Table 8 about here.]

[Table 9 about here.] 


\section{References}

Amenta, Edvin, Sheera Olasky and Neal Caren. 2005. "Age for Leisure? Political Mediation and the Impact of the Pension Movement on U.S. Old-Age Policy." American Sociological Review $70: 516-538$.

Arceneaux, Kevin. 2003. "The Conditional Impact of Blame Attribution on the Relationship Between Economic Adversity and Turnout." Political Research Quarterly 56:67-75.

Austen-Smith, David and John R. Wright. 1994. "Counteractive Lobbying." American Journal of Political Science 38:25-44.

Barreto, Matt A., Gary M. Segura and Nathan D. Woods. 2004. "The Mobilizing Effect of MajorityMinority Districts on Latino Turnout." American Political Science Review 98:65-75.

Baumgartner, Frank R. and Bryan D. Jones. 1993. Agendas and Instability in American Politics. Chicago: University of Chicago Press.

Bobo, Lawrence and Franklin Gilliam. 1990. "Race, Sociopolitical Participation, and Black Political Empowerment." American Political Science Review 84:377-397.

Borjas, George J. and Glenn T. Sueyoshi. 1994. "A Two-Stage Estimator for Probit Models with Structural Group Effects." Journal of Econometrics 64:165-182.

Bowers, Jake. 2004. "Does Moving Disrupt Campaign Activity?” Political Psychology 25:525-543.

Brady, Henry E., Robert Putnam et al. 2001. Roper Social and Political Trends Data, 1973-1994. Data set from Roper Starch Worldwide.

Brady, Henry, Sidney Verba and Kay Lehman Schlozman. 1995. "Beyond SES: A Resource Model of Political Participation." American Political Science Review 89:271-294.

Cameron, Charles, David Epstein and Sharyn O'Halloran. 1996. "Do Majority-Minority Districts Maximize Substantive Black Representation in Congress." American Political Science Review 90:794-812.

Cho, Wendy K. Tam. 2003. "Contagion Effects and Ethnic Contribution Networks." American Journal of Political Science 47:368-387.

Cho, Wendy K. Tam, James G. Gimpel and Joshua J. Dyck. 2006. "Residential Concentration, Political Socialization, and Voter Turnout." Journal of Politics 68:156-167.

Cho, Wendy K. Tam, James G. Gimpel and Tony Wu. 2006. "Clarifying the Role of SES in Political Participation: Policy Threat and Arab American Mobilization." Journal of Politics 68:977-991.

Cobb, Roger, Jennie-Keith Ross and Marc Howard Ross. 1976. "Agenda Building as a Comparative Political Process." American Political Science Review 70:126-138.

Cobb, Roger W. and Charles D. Elder. 1972. Participation in American Politics: The Dynamics of Agenda-Building. Boston: Allyn and Bacon. 
Cress, Daniel M. and David A. Snow. 2000. "The Outcomes of Homeless Mobilization: The Influence of Organization, Disruption, Political Mediation, and Framing." American Journal of Sociology 105:1063-1104.

Dawson, Michael C. 1994. Behind the Mule: Race and Class in African-American Politics. Princeton: Princeton University Press.

Dyke, Nella Van. 2003. "Crossing Movement Boundaries: Factors that Facilitate Coalition Protest by American College Students, 1930-1990." Social Problems 50:226-250.

Dyke, Nella Van and Sarah A. Soule. 2002. "Structural Social Change and the Mobilizing Effect of Threat: Explaining Levels of Patriot and Militia Organizing in the United States." Social Problems 49:497-520.

Feldman, Stanley. 1982. "Economic Self-Interest and Political Behavior." American Journal of Political Science 26:446-466.

Fenno, Richard F. 1978. Home Style. New York: HarperCollins.

Gay, Claudine. 2001. "The Effect of Black Congressional Representation on Political Participation." American Political Science Review 95:589-617.

Gay, Claudine. 2002. "Spirals of Trust? The Effect of Descriptive Representation on the Relationship between Citizens and Their Government." American Journal of Political Science 46:717-732.

Gay, Claudine. 2004. "Putting Race in Context: Identifying the Environmental Determinants of Black Racial Attitudes." American Political Science Review 98:547-562.

Griffin, John D. and Michael Keane. 2006. "Descriptive Representation and the Composition of African American Turnout." American Journal of Political Science 50:998-1012.

Gurin, Patricia, Shirley Hatchett and James Jackson. 1989. Hope and Independence: Blacks' REsponse to Electoral and Party Politics. New York: Russell Sage Foundation.

Guterbock, Thomas M. and Bruce London. 1983. "Race, Political Orientation, and Participation: An Empirical Test of Four Competing Theories." American Sociological Review 48:439-453.

Hamilton, Dona C. and Charles V. Hamilton. 1997. The Dual Agenda: Race and Social Welfare Policies of Civil Rights Organizations. New York: Columbia University Press.

Harris, Fredrick C., Valeria Sinclair-Chapman and Brian McKenzie. 2006. Countervailing Forces in African-American Civic Activism, 1973 - 1994. Cambridge: Cambridge University Press.

Huber, John D., Georgia Kernell and Eduardo L. Leoni. 2005. "Institutional Context, Cognitive Resources and Party Attachments Across Democracies." Political Analysis 13:365-386.

Jenkins, J. Craig, David Jacobs and Jon Agnone. 2003. "Political Opportunities and AfricanAmerican Protest, 1948-1997." American Journal of Sociology 109:277-303.

Johnson, Martin, Robert M. Stein and Robert Wrinkle. 2003. "Language Choice, Residential Stability, and Voting Among Latino Americans." Social Science Quarterly 84:412-424. 
Jones, Bryan D. and Frank R. Baumgartner. 2005. The Politics of Attention: How Government Prioritizes Problems. Chicago: University of Chicago Press.

Kenny, Christopher B. 1992. "Political Participation and Effects from the Social Environment." American Journal of Political Science 36:259-267.

Kinder, Donald R. and D. Roderick Kiewiet. 1979. "Economic Discontent and Political Behavior: The Role of Personal Grievances and Collective Economic Judgments in Congressional Voting." American Journal of Political Science 23:495-527.

King, Gary, Michael Tomz and Jason Wittenberg. 2000. "Making the Most of Statistical Analysis: Improving Interpretation and Presentation." American Journal of Political Science 44:341-355.

Kollman, Ken. 1998. Outside Lobbying: Public Opinion and Interest Group Strategies. Princeton: Princeton University Press.

Krysan, Maria. 2000. "Prejudice, Politics, and Public Opinion: Understanding the Sources of Racial Policy Attitudes." Annual Review of Sociology 26:135-168.

Lawless, Jennifer L. 2004. "Politics of Presence? Congresswomen and Symbolic Representation." Political Research Quarterly 57:81-99.

Lee, Taeku. 2002. Mobilizing Public Opinion: Black Insurgency and Racial Attitudes in the Civil Rights Era. Chicago: University of Chicago Press.

Leighley, Jan. 1996. "Group Membership and the Mobilization of Political Participation." Journal of Politics 58:447-463.

Lohmann, Susanne. 1993. "A Signalling Model of Informative and Manipulative Political Action." American Political Science Review 87:319-333.

Lohmann, Susanne. 1994. "The Dynamics of Informational Cascades: The Monday Demonstrations in Leipzig, East Germany, 1989-1991." World Politics 47:42-101.

Lublin, David. 1997. The Paradox of Representation: Racial Gerrymandering and Minority Interests in Congress. Princeton: Princeton University Press.

Mangum, Maurice. 2003. "Psychological Involvement and Black Voter Turnout." Politcal Research Quarterly 56:41-48.

Marschall, Melissa J. 2001. "Does the Shoe Fit? Testing Models of Participation for AfricanAmerican and Latino Involvement in Local Politics." Urban Affairs Review 37:227-248.

Marschall, Melissa J. 2004. "Citizen Participation and the Neighborhood Context: A New Look at the Coproduction of Local Public Goods." Political Research Quarterly 57:231-244.

McAdam, Doug. 1999. Political Process and the Development of Black Insurgency, 1930-1970. Second ed. Chicago: University of Chicago Press.

McAdam, Doug and Ronnelle Paulsen. 1993. "Specifying the Relationship Between Social Ties and Activism." American Journal of Sociology 99:640-667. 
McAdam, Doug, Sidney Tarrow and Charles Tilly. 2001. Dynamics of Contention. Cambridge: Cambridge University Press.

McCammon, Holly J., Karen E. Campbell, Ellen M. Granberg and Christine Mowery. 2001. "How Movements Win: Gendered Opportunity Structures and U.S. Women's Suffrage Movements, 1866 to 1919." American Sociological Review 66:49-70.

McClain, Paula D., ed. 1993. Minority Group Influence: Agenda-Setting, Formulation, and Public Policy. Westport, Connecticut: Greenwood Press.

McClurg, Scott D. 2003. "Social Networks and Political Participation: The Role of Social Interaction in Explaining Political Participation." Political Research Quarterly 56:449-464.

Meyer, David S. 2004. "Protest and Political Opportunities." Annual Review of Sociology 30:125145.

Morris, Aldon. 1984. Origins of the Civil Rights Movement: Black Communities Organizing for Change. New York: Free Press.

Olson, Mancur. 1971. Logic of Collective Action. Cambridge: Harvard University Press.

Peffley, Mark, Jon Hurwitz and Paul M. Sniderman. 1997. "Racial Stereotypes and Whites' Political Views of Black in the Context of Welfare and Crime." American Journal of Political Science 41:30-60.

Riker, William H. and Peter C. Ordeshook. 1968. "A Theory of the Calculus of Voting." American Political Science Review 62:25-42.

Rosenstone, Steven and John Mark Hansen. 1993. Mobilization, Participation, and Democracy. New York: Macmillan.

Schattschneider, E.E. 1975. Semisovereign People: A Realist's View of Democracy in America. New York: Dryden Press.

Schlozman, Kay Lehman, Sidney Verba and Henry E. Brady. 1995. "Participation's Not a Paradox: The View from American Activists." British Journal of Political Science 25:1-36.

Schussman, Alan and Sarah A. Soule. 2005. "Process and Protest: Accounting for Individual Protest Participation." Social Forces 84:1083-1108.

Sears, David O., Carl P. hensler and Leslie K. Speer. 1979. "Whites' Opposition to "Busing": Self-Interest or Symbolic Politics?" American Political Science Review 73:369-384.

Sheingate, Adam D. 2006. "Structure and Opportunity: Committee Jurisdiction and Issue Attention in Congress." American Journal of Political Science 50:844-860.

Shingles, Richard D. 1981. "Black Consciousness and Political Participation: The Missing Link." The American Political Science Review 75:76-91. 
Smith, Robert C. 1992. "Politics" is Not Enough: The Institutionalization of the African American Freedom Movement. In From Exclusion to Inclusion: The Long Struggle for African American Political Power, ed. Ralph C. Gomes and Linda Faye Williams. New York: Greenwood Press pp. $97-126$.

Smith, Robert C. 1996. We Have No Leaders: African-Americans in the Post-Civil Rights Era. Albany: State University of New York Press.

Sniderman, Paul M., Edward G. Carmines, Geoffrey C. Layman and Michael Carter. 1996. "Beyond Race: Social Justice as a Race Neutral Ideal." American Journal of Political Science 40:33-55.

Sniderman, Paul M., Thomas Piazza, Philip E. Tetlock and Ann Kendrick. 1991. "The New Racism." American Journal of Political Science 35:423-447.

Soule, Sarah A. 1997. "The Student Divestment Movement in the United States and Tactical Diffusion: The Shantytown Protest." Social Forces 75:855-882.

Soule, Sarah A. and Yvonne Zylan. 1997. "Runaway Train? The Diffusion of State-Level Reform in ADC/AFDC Eligibility Requirements, 1950-1967." American Journal of Sociology 103:733-762.

Southwell, Priscilla L. and Kevin D. Pirch. 2003. "Political Cynicism and the Mobilization of Black Voters." Social Science Quarterly 84:906-917.

Swain, Carol. 1995. Black Faces, Black Interests: The Representation of African Americans in Congress. Cambridge: Harvard University Press.

Tarman, Christopher and David O. Sears. 2005. "The Conceptualization and Measurement of Symbolic Racism." Journal of Politics 67:731-761.

Tate, Katherine. 1994. From Protest to Politics: The New Black Voters in American Elections. Enlarged ed. Cambridge: Harvard University Press.

Verba, Sidney, Kay Lehman Schlozman and Henry E. Brady. 1995. Voice and Equality: Civic Voluntarism in American Politics. Cambridge: Harvard University Press.

Verba, Sidney and Norman Nie. 1972. Participation in America. New York: Harper and Row.

Virtanen, Simo V. and Leonie Huddy. 1998. "Old-Fashioned Racism and New Forms of Racial Prejudice." Journal of Politics 60:311-332.

Walton, Hanes. 1988. When the Marching Stopped: The Politics of Civil Rights of Regulatory Agencies. Albany: State University of New York Press.

Walton, Hanes, Jr. 1985. Invisible Politics: Black Political Behavior. Albany: State University of New York Press.

Walton, Hanes and Robert C. Smith. 2003. American Politics and the African American Quest for Universal Freedom. 2nd ed. New York: Longman Publishers.

Welch, Susan and Lorn S. Foster. 1992. "The Impact of Economic Conditions on the Voting Behavior of Blacks." Western Political Quarterly 45:221. 


\section{List of Figures}

1 The Predicted Probability of Black Participation, 1980-1994 . . . . . . . . . . . . 27

2 Participation Rates and Racial Differences, 1973-1994 . . . . . . . . . . . . . . 28 
Figure 1: The Predicted Probability of Black Participation, 1980-1994

(a) Overall Participation

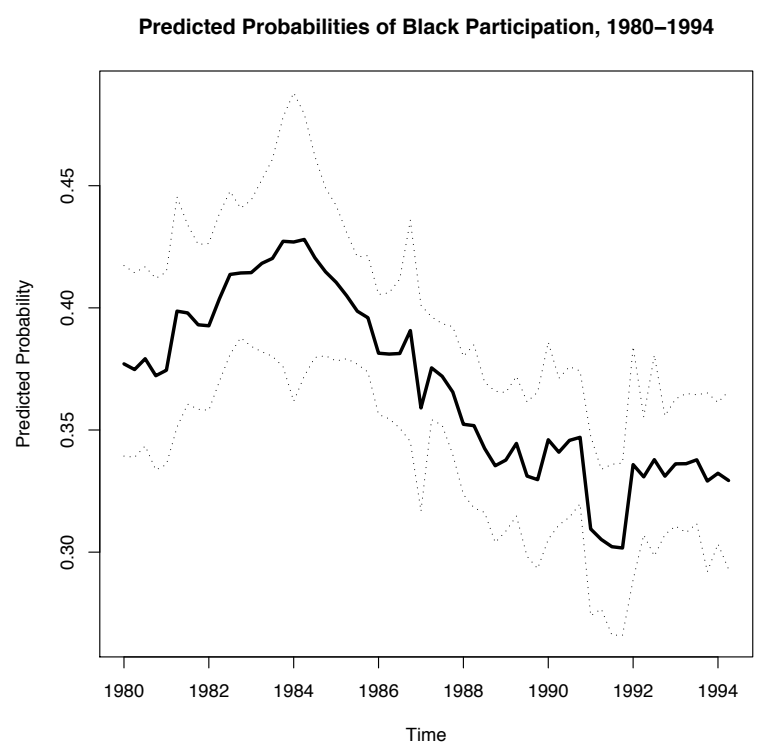

(b) Party Work

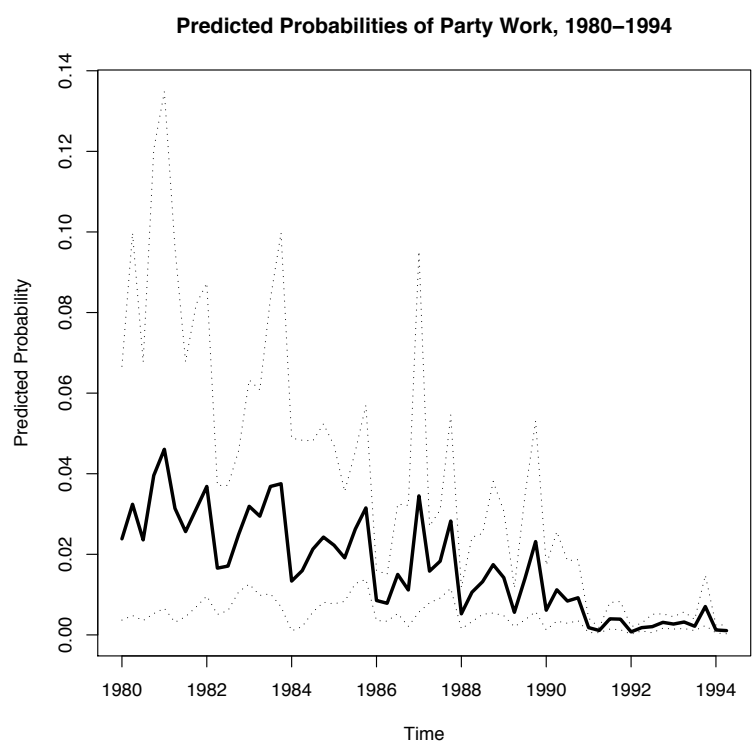


Figure 2: Participation Rates and Racial Differences, 1973-1994

(a) Black and White Participation Rates

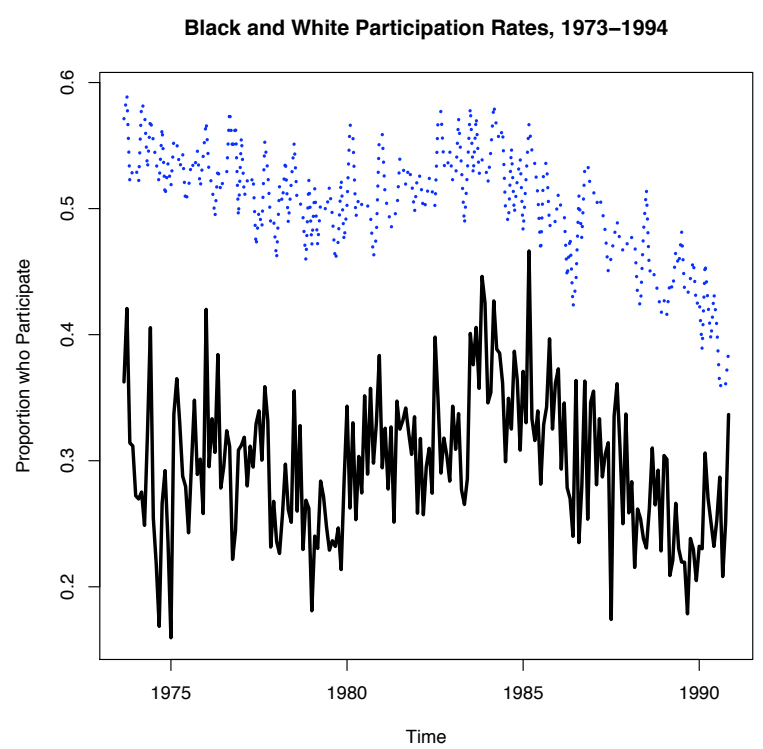

(b) Racial Differences in Participation Rates

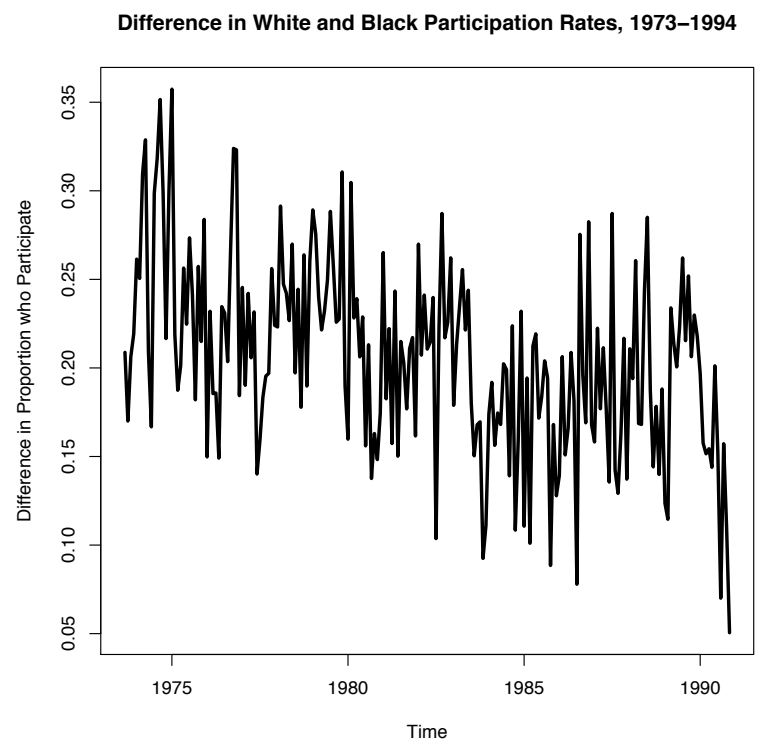




\section{List of Tables}

1 The Impact of Opportunities on Black Participation: These are the first differences in the predicted probabilities of participation given a standard deviation from the baseline. Columns are labeled by the dependent variable. Bold entries indicate statistical significance, and the parentheses contain the $95 \%$ confidence interval. . . . . . . . . . . . . . . . . . . . . . . . .

2 The Interaction Effects of Organizational Activity: These are first differences when an individual becomes involved in organizational activity and there is a standard deviation increase in the row variables. Bold entries mark an enhanced effect for those involved in organizational activity. . . . .

3 The Interaction Effects of Education: These are first differences when an individual's education rises by one level and there is a standard deviation increase in the row variables. Bold entries mark an enhanced effect for those with higher education levels. . . . . . . . . . . . . . . . . .

4 The Interaction Effects of Income: These are first differences when an individual's income rises by one standard deviation and there is a standard deviation increase in the row variables. Bold entries mark an enhanced effect for those with higher income levels. . . . . . . . . . . . . . . . .

5 Relationship Between Congressional Hearings and Black Participation: The cell entries are standard poisson coefficients. Each model includes a different measure of black participation. The collinearity between these measures was too great for them all to be included within one model. . . . . . . . . 34

6 Results - General Participation . . . . . . . . . . . . . . . . . . . . . . . . . 35

7 Results - Petitions ... . . . . . . . . . . . . . . . . . . . . 36

8 Results - Party Work . . . . . . . . . . . . . . . . . . . . . . 37

9 Results - Rally Attendance . . . . . . . . . . . . . . . . . . . . . . . 38 


\begin{tabular}{|c|c|c|c|c|}
\hline & Participation & Petitions & Party & Rally \\
\hline \multicolumn{5}{|l|}{ Threats } \\
\hline Black Unemployment & $\begin{array}{c}0.008 \\
(-0.005 / 0.023)\end{array}$ & $\begin{array}{c}0.000 \\
(-0.007 / 0.008)\end{array}$ & $\begin{array}{c}-0.000 \\
(-0.001 / 0.000)\end{array}$ & $\begin{array}{c}0.002 \\
(-0.001 / 0.005)\end{array}$ \\
\hline Reagan Threat & $\begin{array}{c}\mathbf{0 . 0 6 7} \\
(0.041 / 0.093)\end{array}$ & $\begin{array}{c}\mathbf{0 . 0 3 8} \\
(0.022 / 0.054)\end{array}$ & $\begin{array}{c}\mathbf{0 . 0 1 5} \\
(0.008 / 0.025)\end{array}$ & $\begin{array}{c}\mathbf{0 . 0 1 6} \\
(0.008 / 0.023)\end{array}$ \\
\hline \multicolumn{5}{|l|}{ Access } \\
\hline Black Bills & $\begin{array}{c}0.002 \\
(-0.008 / 0.013)\end{array}$ & $\begin{array}{c}0.006 \\
(-0.001 / 0.014)\end{array}$ & $\begin{array}{c}\mathbf{0 . 0 0 1} \\
(0.000 / 0.002)\end{array}$ & $\begin{array}{c}-0.001 \\
(-0.003 / 0.001)\end{array}$ \\
\hline Black Chairs & $\begin{array}{c}-0.007 \\
(-0.019 / 0.006)\end{array}$ & $\begin{array}{c}-0.004 \\
(-0.012 / 0.004)\end{array}$ & $\begin{array}{c}\mathbf{- 0 . 0 0 1} \\
(-0.001 /-0.000)\end{array}$ & $\begin{array}{c}-0.002 \\
(-0.005 / 0.000)\end{array}$ \\
\hline Percent Conservative & $\begin{array}{c}-0.005 \\
(-0.014 / 0.006)\end{array}$ & $\begin{array}{c}-0.002 \\
(-0.007 / 0.004)\end{array}$ & $\begin{array}{c}\mathbf{- 3 . 5 1 e - 4} \\
(-6.39 \mathrm{e}-4 /-7.43 \mathrm{e}-5)\end{array}$ & $\begin{array}{c}-0.001 \\
(-0.003 / 0.002)\end{array}$ \\
\hline \multicolumn{5}{|l|}{ Networks } \\
\hline Organizational Activity & $\begin{array}{c}\mathbf{0 . 8 2 6} \\
(0.810 / 0.841)\end{array}$ & $\begin{array}{c}\mathbf{0 . 3 4 1} \\
(0.280 / 0.403)\end{array}$ & $\begin{array}{c}\mathbf{0 . 0 2 7} \\
(0.018 / 0.040)\end{array}$ & $\begin{array}{c}\mathbf{0 . 1 5 7} \\
(0.117 / 0.203)\end{array}$ \\
\hline \multicolumn{5}{|l|}{ Controls } \\
\hline Education & $\begin{array}{c}\mathbf{0 . 1 7 4} \\
(0.140 / 0.210)\end{array}$ & $\begin{array}{c}\mathbf{0 . 1 2 4} \\
(0.102 / 0.146)\end{array}$ & $\begin{array}{c}\mathbf{0 . 0 0 7} \\
(0.002 / 0.015)\end{array}$ & $\begin{array}{c}\mathbf{0 . 0 3 1} \\
(0.018 / 0.046)\end{array}$ \\
\hline Age & $\begin{array}{c}-0.000 \\
(-0.023 / 0.022)\end{array}$ & $\begin{array}{c}0.002 \\
(-0.011 / 0.015)\end{array}$ & $\begin{array}{c}0.000 \\
(-0.001 / 0.001)\end{array}$ & $\begin{array}{c}0.002 \\
(-0.003 / 0.008)\end{array}$ \\
\hline Income & $\begin{array}{c}\mathbf{0 . 7 2 1} \\
(0.592 / 0.801)\end{array}$ & $\begin{array}{c}\mathbf{0 . 7 4 3} \\
(0.509 / 0.874)\end{array}$ & $\begin{array}{c}0.056 \\
(-0.000 / 0.255)\end{array}$ & $\begin{array}{c}0.039 \\
(-0.012 / 0.166)\end{array}$ \\
\hline
\end{tabular}

Table 1: The Impact of Opportunities on Black Participation: These are the first differences in the predicted probabilities of participation given a standard deviation from the baseline. Columns are labeled by the dependent variable. Bold entries indicate statistical significance, and the parentheses contain the $95 \%$ confidence interval. 


\begin{tabular}{lcccc}
\hline \hline & & & & \\
& Participation & Petitions & Party & Rally \\
\hline \hline Base Organization & 0.826 & 0.341 & 0.027 & 0.157 \\
& $(0.810 / 0.841)$ & $(0.280 / 0.403)$ & $(0.018 / 0.040)$ & $(0.117 / 0.203)$ \\
Black Unemployment & 0.817 & $\mathbf{0 . 3 6 5}$ & $\mathbf{0 . 0 3 5}$ & $\mathbf{0 . 1 6 7}$ \\
& $(0.787 / 0.842)$ & $(0.275 / 0.453)$ & $(0.017 / 0.062)$ & $(0.104 / 0.246)$ \\
Reagan Threat & -0.210 & 0.268 & $\mathbf{0 . 0 9 3}$ & $\mathbf{0 . 2 1 7}$ \\
& $(-0.253 /-0.087)$ & $(0.217 / 0.322)$ & $(0.055 / 0.133)$ & $(0.177 / 0.261)$ \\
Black Bills & 0.814 & 0.303 & & 0.151 \\
& $(0.777 / 0.838)$ & $(0.235 / 0.373)$ & $(0.023 / 0.060)$ & $(0.110 / 0.198)$ \\
Black Chairs & & & 0.016 & $\mathbf{0 . 1 6 9}$ \\
& $\mathbf{0 . 8 3 3}$ & $\mathbf{0 . 3 7 9}$ & $0.059 / 0.026)$ & $(0.105 / 0.244)$ \\
Percent Conservative & $(0.809 / 0.856)$ & $(0.292 / 0.466)$ & $(0.009)$ & \\
& $(0.808 / 0.852)$ & $(0.261 / 0.425)$ & $(0.011 / 0.034)$ & $(0.107 / 0.227)$ \\
& & & & \\
\hline
\end{tabular}

Table 2: The Interaction Effects of Organizational Activity: These are first differences when an individual becomes involved in organizational activity and there is a standard deviation increase in the row variables. Bold entries mark an enhanced effect for those involved in organizational activity. 


\begin{tabular}{|c|c|c|c|c|}
\hline & Participation & Petitions & Party & Rally \\
\hline Base Education & $\begin{array}{c}0.174 \\
(0.140 / 0.210)\end{array}$ & $\begin{array}{c}0.124 \\
(0.102 / 0.146)\end{array}$ & $\begin{array}{c}0.007 \\
(0.002 / 0.015)\end{array}$ & $\begin{array}{c}0.031 \\
(0.018 / 0.046)\end{array}$ \\
\hline Black Unemployment & $\begin{array}{c}\mathbf{0 . 1 8 3} \\
(0.127 / 0.240)\end{array}$ & $\begin{array}{c}\mathbf{0 . 1 4 1} \\
(0.105 / 0.177)\end{array}$ & $\begin{array}{c}\mathbf{0 . 0 1 1} \\
(0.001 / 0.031)\end{array}$ & $\begin{array}{c}\mathbf{0 . 0 3 2} \\
(0.012 / 0.057)\end{array}$ \\
\hline Reagan Threat & $\begin{array}{c}0.135 \\
(0.110 / 0.162)\end{array}$ & $\begin{array}{c}0.105 \\
(0.086 / 0.125)\end{array}$ & $\begin{array}{c}-0.005 \\
(-0.018 / 0.005)\end{array}$ & $\begin{array}{c}0.024 \\
(0.011 / 0.038)\end{array}$ \\
\hline Black Bills & $\begin{array}{c}\mathbf{0 . 1 7 6} \\
(0.142 / 0.213)\end{array}$ & $\begin{array}{c}0.122 \\
(0.097 / 0.148)\end{array}$ & $\begin{array}{c}0.002 \\
(-0.000 / 0.006)\end{array}$ & $\begin{array}{c}0.022 \\
(0.012 / 0.033)\end{array}$ \\
\hline Black Chairs & $\begin{array}{c}0.160 \\
(0.111 / 0.215)\end{array}$ & $\begin{array}{c}\mathbf{0 . 1 2 7} \\
(0.095 / 0.161)\end{array}$ & $\begin{array}{c}0.007 \\
(0.001 / 0.020)\end{array}$ & $\begin{array}{c}0.029 \\
(0.013 / 0.049)\end{array}$ \\
\hline Percent Conservative & $\begin{array}{c}\mathbf{0 . 1 7 7} \\
(0.131 / 0.224)\end{array}$ & $\begin{array}{c}\mathbf{0 . 1 3 1} \\
(0.102 / 0.161)\end{array}$ & $\begin{array}{c}\mathbf{0 . 0 1 0} \\
(0.002 / 0.024)\end{array}$ & $\begin{array}{c}0.027 \\
(0.012 / 0.047)\end{array}$ \\
\hline
\end{tabular}

Table 3: The Interaction Effects of Education: These are first differences when an individual's education rises by one level and there is a standard deviation increase in the row variables. Bold entries mark an enhanced effect for those with higher education levels. 


\begin{tabular}{lcc}
\hline \hline & Participation & Petitions \\
\hline \hline Base Income & 0.721 & 0.743 \\
& $(0.592 / 0.801)$ & $(0.509 / 0.874)$ \\
Black Unemployment & $\mathbf{0 . 7 3 4}$ & $\mathbf{0 . 7 7 0}$ \\
& $(0.565 / 0.814)$ & $(0.455 / 0.898)$ \\
Reagan Threat & $\mathbf{0 . 7 3 8}$ & $\mathbf{0 . 8 4 0}$ \\
& $(0.709 / 0.761)$ & $(0.797 / 0.865)$ \\
Black Bills & $\mathbf{0 . 7 8 2}$ & $\mathbf{0 . 8 3 7}$ \\
& $(0.724 / 0.819)$ & $(0.730 / 0.889)$ \\
Black Chairs & 0.531 & 0.494 \\
& $(0.141 / 0.784)$ & $(0.044 / 0.855)$ \\
Percent Conservative & $\mathbf{0 . 7 4 2}$ & 0.710 \\
& $(0.574 / 0.825)$ & $(0.356 / 0.885)$ \\
& & \\
\hline
\end{tabular}

Table 4: The Interaction Effects of Income: These are first differences when an individual's income rises by one standard deviation and there is a standard deviation increase in the row variables. Bold entries mark an enhanced effect for those with higher income levels. 


\begin{tabular}{lcccc}
\hline \hline & & & & \\
& Model 1 & Model 2 & Model 3 & Model 4 \\
\hline \hline Intercept & 0.363 & 0.354 & 0.288 & 0.606 \\
& $(0.923)$ & $(0.911)$ & $(0.918)$ & $(0.914)$
\end{tabular}

\section{Political Participation}

$\begin{array}{cc}0.001 \\ \text { Participation } & (0.013)\end{array}$

Rally

$-0.029$

$(0.028)$

Petition

0.020

(0.018)

Party

$-0.083$

$(0.042)$

Access

\begin{tabular}{lcccc} 
Percent Conservative & 0.027 & 0.031 & 0.025 & 0.028 \\
& $(0.026)$ & $(0.026)$ & $(0.026)$ & $(0.025)$ \\
Black Chairs & & & & \\
& 0.005 & 0.012 & -0.005 & 0.010 \\
& $(0.018)$ & $(0.017)$ & $(0.019)$ & $(0.016)$ \\
Black Bills & & & & \\
& $\mathbf{0 . 0 2 6}$ & $\mathbf{0 . 0 2 2}$ & $\mathbf{0 . 0 2 9}$ & $\mathbf{0 . 0 2 2}$ \\
& $(0.008)$ & $(0.008)$ & $(0.008)$ & $(0.008)$ \\
\hline N & & & & \\
Likelihood & 58 & 58 & 58 & 58 \\
\hline & -243.38 & -243.94 & -243.98 & -245.39 \\
\hline
\end{tabular}

Table 5: Relationship Between Congressional Hearings and Black Participation: The cell entries are standard poisson coefficients. Each model includes a different measure of black participation. The collinearity between these measures was too great for them all to be included within one model. 
Table 6: Results - General Participation

\begin{tabular}{lccccc}
\hline \hline & & & & & \\
& Intercept & Organization & Income & Education & Age \\
\hline \hline Intercept & -1.011 & -103.947 & -0.162 & 0.910 & -0.104 \\
& $(0.927)$ & $(31.80)$ & $(1.113)$ & $(1.002)$ & $(0.194)$ \\
Unemployment & 0.021 & 0.653 & 0.018 & 0.010 & 0.006 \\
& $(0.023)$ & $(0.780)$ & $(0.022)$ & $(0.022)$ & $(0.004)$ \\
& & & & & \\
Reagan & 0.415 & -13.552 & 0.129 & -0.142 & -0.008 \\
& $(0.096)$ & $(2.089)$ & $(0.115)$ & $(0.109)$ & $(0.020)$ \\
Bills Introduced & 0.003 & -0.277 & 0.014 & 0.001 & -0.001 \\
& $(0.006)$ & $(0.182)$ & $(0.006)$ & $(0.006)$ & $(0.001)$ \\
Allies & & & & & \\
& -0.014 & 2.052 & -0.029 & -0.019 & -0.002 \\
Conservative & $(0.013)$ & $(0.454)$ & $(0.015)$ & $(0.013)$ & $(0.002)$ \\
& & & & & \\
\multirow{2}{*}{$\begin{array}{l}\text { N } \\
\text { deviance }\end{array}$} & $(0.018$ & 2.034 & 0.023 & 0.006 & 0.002 \\
\hline
\end{tabular}


Table 7: Results - Petitions

\begin{tabular}{lccccc}
\hline \hline & & & & & \\
& Intercept & Organization & Income & Education & Age \\
\hline \hline Intercept & -1.791 & 0.655 & 0.687 & 0.642 & -0.017 \\
& $(0.934)$ & $(1.868)$ & $(1.374)$ & $(0.885)$ & $(0.234)$ \\
Unemployment & -0.001 & 0.003 & 0.022 & 0.015 & 0.002 \\
& $(0.021)$ & $(0.037)$ & $(0.028)$ & $(0.021)$ & $(0.004)$ \\
& & & & & \\
Reagan & 0.377 & -0.280 & 0.180 & -0.175 & -0.030 \\
& $(0.097)$ & $(0.198)$ & $(0.153)$ & $(0.099)$ & $(0.024)$ \\
Bills Introduced & 0.010 & -0.035 & 0.017 & -0.004 & -0.001 \\
& $(0.006)$ & $(0.012)$ & $(0.008)$ & $(0.006)$ & $(0.001)$ \\
Allies & & & & & \\
& -0.012 & 0.021 & -0.035 & -0.007 & -0.001 \\
Conservative & $(0.013)$ & $(0.023)$ & $(0.017)$ & $(0.012)$ & $(0.003)$ \\
& & & & & \\
\multirow{2}{*}{$\begin{array}{l}\text { N } \\
\text { deviance }\end{array}$} & $(0.021)$ & $(0.044)$ & $(0.032)$ & $(0.020)$ & $(0.005)$ \\
\hline
\end{tabular}


Table 8: Results - Party Work

\begin{tabular}{lccccc}
\hline \hline & & & & & \\
& Intercept & Organization & Income & Education & Age \\
\hline \hline Intercept & 9.776 & 6.321 & 5.701 & -16.772 & -2.425 \\
& $(5.214)$ & $(5.003)$ & $(3.188)$ & $(6.395)$ & $(0.712)$ \\
Unemployment & -0.116 & 0.041 & -0.135 & 0.080 & 0.012 \\
& $(0.115)$ & $(0.107)$ & $(0.070)$ & $(0.137)$ & $(0.015)$ \\
& & & & & \\
Reagan & 2.773 & -0.111 & -0.064 & -1.261 & -0.356 \\
& $(0.432)$ & $(0.586)$ & $(0.311)$ & $(0.537)$ & $(0.064)$ \\
Bills Introduced & 0.081 & -0.031 & 0.042 & -0.185 & -0.013 \\
& $(0.029)$ & $(0.032)$ & $(0.018)$ & $(0.035)$ & $(0.004)$ \\
Allies & & & & & \\
& -0.391 & 0.041 & -0.005 & 0.182 & 0.040 \\
Conservative & $(0.075)$ & $(0.073)$ & $(0.0 .041)$ & $(0.081)$ & $(0.009)$ \\
& & & & & \\
\multirow{N}{N}{ deviance } & -0.248 & -0.133 & -0.112 & 0.461 & 0.057 \\
\hline
\end{tabular}


Table 9: Results - Rally Attendance

\begin{tabular}{lccccc}
\hline \hline & & & & & \\
& Intercept & Organization & Income & Education & Age \\
\hline \hline Intercept & -2.827 & 1.445 & 1.644 & 4.586 & -0.297 \\
& $(1.839)$ & $(3.165)$ & $(1.585)$ & $(1.876)$ & $(0.379)$ \\
Unemployment & 0.027 & -0.097 & -0.024 & 0.003 & 0.022 \\
& $(0.042)$ & $(0.068)$ & $(0.036)$ & $(0.045)$ & $(0.009)$ \\
& & & & & \\
Reagan & 0.681 & 0.180 & 0.400 & -0.209 & -0.069 \\
& $(0.184)$ & $(0.332)$ & $(0.176)$ & $(0.206)$ & $(0.043)$ \\
Bills Introduced & -0.007 & 0.020 & 0.009 & 0.003 & 0.001 \\
& $(0.009)$ & $(0.019)$ & $(0.011)$ & $(0.011)$ & $(0.002)$ \\
Allies & & & & & \\
& -0.042 & 0.016 & -0.065 & -0.021 & 0.001 \\
Conservative & $(0.026)$ & $(0.043)$ & $(0.020)$ & $(0.025)$ & $(0.005)$ \\
& -0.022 & 0.051 & -0.002 & -0.095 & 0.001 \\
N & $(0.042)$ & $(0.070)$ & $(0.035)$ & $(0.041)$ & $(0.009)$ \\
deviance & 58 & 58 & 58 & 58 & 58 \\
\hline
\end{tabular}

